\title{
Impacts of Mastication: Soil Seed Bank Responses to a Forest Thinning Treatment in Three Colorado (USA) Conifer Forest Types
}

\author{
Akasha M. Faist ${ }^{1, *}$, Heather Stone ${ }^{1}$ and Erin A. Tripp ${ }^{1,2}$ \\ 1 Department of Ecology and Evolutionary Biology, University of Colorado, Boulder, CO 80309, \\ USA; E-Mail: heather.blair.stone@gmail.com \\ 2 University of Colorado Museum of Natural History, University of Colorado, Boulder, CO 80309, \\ USA; E-Mail: Erin.Tripp@colorado.edu \\ * Author to whom correspondence should be addressed; E-Mail: akasha.faist@colorado.edu \\ Academic Editors: Robert Wagner and Eric J. Jokela
}

Received: 9 July 2015 / Accepted: 25 August 2015 / Published: 31 August 2015

\begin{abstract}
Mastication is a forest fuel thinning treatment that involves chipping or shredding small trees and shrubs and depositing the material across the forest floor. By decreasing forest density mastication has been shown to lessen crown fire hazard, yet other impacts have only recently started to be studied. Our study evaluates how mastication treatments alter the density and composition of soil seed banks in three Colorado conifer forest types. The three forest types were (1) lodgepole pine, (2) ponderosa pine and (3) pinyon pine-juniper. Results showed that masticated sites contained higher seed bank densities than untreated sites: a pattern primarily driven by treatment effects in ponderosa pine forests. The seed bank was dominated by forbs regardless of forest type or treatment. This pattern of forb dominance was not observed in the aboveground vegetation cover as it demonstrated more even proportions of the functional groups. Graminoids showed a higher seed density in treated sites than untreated and, similarly, the identified non-native species only occurred in the treated ponderosa pine sites suggesting a potential belowground invasion for this forest type. These results suggest that presence of masticated material might not be creating a physical barrier hindering the transfer of seeds as predicted.
\end{abstract}


Keywords: conifer; vegetation; seed banks; ponderosa; Lodgepole; pinyon-juniper

\section{Introduction}

Following decades of fire suppression and climate change, the severity and frequency of forest wildfires are increasing across multiple ecosystems [1-6]. Increasing fire hazards and fuel densities coupled with human encroachment into the wildland urban interface have prompted managers to implement fuel reduction treatments to reduce potential crown fire hazard and threat to property [3,5,7-10]. One such fuels reduction treatment is mastication or the chipping or shredding of unwanted small diameter trees and shrubs, followed by broadcasting this material, commonly called mulch, across the treatment area $[10,11]$. Mastication has recently become implemented across many forest types and is now widely used because it is cost-effective, easily implemented and has been shown to modify fire behavior to reduce crown fire hazard [7,12].

As fuels are not removed from the site following mastication, the treatment results in greater biomass distributed onto the forest floor [8,11,13-17]. A heterogeneous deposition of masticated materials, or mulch, can lead to variable responses in understory plant cover [18-23]. At stand level scales, such as over an entire thinning project, mulching has been shown to increase plant diversity and cover due to an increase in light and the maintenance and enhancement of soil moisture $[16,18,20]$.

However, when looking at the system at a finer spatial scale (e.g., $\mathrm{m}_{2}$ ), the heterogeneity of forest floor fuel depths can have a range of positive and negative effects on the understory vegetation community [16,18-24]. Yet defining a vegetation community solely as the active aboveground composition is often incomplete as other species may be waiting to emerge from the belowground seed bank following environmental or structural shifts [25] such as a fuel thinning treatment. While the presence of masticated material can elicit a variety of responses from the aboveground vegetation community, we have yet to understand how the seed bank, and the potential future colonizers of a community, might be altered by this process.

Many plant species rely on seed banks, or the storage of propagules belowground, as a mechanism for dealing with unfavorable conditions [26-29]. Seed banking strategies, such as persistence, are often correlated with natural or human induced disturbances, [30]; thus, disturbances can elicit highly variable seed bank release responses. However, ecological disturbances commonly are due to the removal of biomass, such as through a forest fire [31], or through redistribution and loss of soil layers [32]. While varying in duration and intensity, natural disturbances often leave large areas of exposed soil that facilitate the release of the stored seed bank adapted to exploit gaps [30,33]. On the contrary, mastication adds plant biomass to the forest floor, thereby leading to the need to understand seed bank dynamics and general treatment effects on understory plant communities and their associated seed banks.

To explore how mastication treatments affect seed bank density and composition, we initiated a study in three Colorado (USA) conifer forest types-lodgepole pine (Pinus contorta Douglas ex Loudon), ponderosa pine (Pinus ponderosa Lawson and C. Lawson) and pinyon pine-juniper (Pinus edulis Engelm.-Juniperus L. spp.). We asked two questions: (1) how do mastication treatments impact seed bank densities, both in total and by plant functional groups (i.e., graminoid, forb, shrub, tree)? and 
(2) are the changes in aboveground functional group composition mirrored by the seed bank? We hypothesized that mastication would provide a physical barrier hindering the transfer of seeds from above and over time only persistent seeds would remain due to a blocked pathway. This loss of seed transfer could enhance species that rely on seed banks to persist, such as annual forbs, and hinder those that exhibit low seed bank longevity, such as commonly found amongst trees and grasses. We also hypothesized that the aboveground vegetation would not be mirrored by the seed bank, because the physical barrier would cause a filter limiting what would be able to reach the aboveground vegetation, thus exacerbating the disparity between the above and belowground vegetation types.

\section{Methods}

\subsection{Study Area and Design}

Our study utilized nine sites in Colorado, USA, (both federally and state owned) that had been treated to reduce crown fire hazard and were a subset of long term plots established by Battaglia et al. [15,16]. Three sites were located in each of three conifer dominated forest types: (1) pinyon pine-juniper (hereafter referred to as pinyon-juniper), (2) ponderosa pine and (3) lodgepole pine. The pinyon-juniper forests were lowest in elevation (1915 to $2250 \mathrm{~m})$ with an annual precipitation between 5.1 and $7.3 \mathrm{~cm}$ and annual average maximum and minimum temperatures of 16.5 to $18.1{ }^{\circ} \mathrm{C}$ and -0.6 to $2.6{ }^{\circ} \mathrm{C}$, respectively. The ponderosa pine sites were designated as the mid elevation sites (2100 to $2360 \mathrm{~m}$ ) and were generally dominated by ponderosa pine, but also often contained a high occurrence of Douglas-fir (Pseudotsuga menziesii (Mirb.) Franco). The ponderosa pine sites receive an annual precipitation between 6.3 and $8.1 \mathrm{~cm}$, and average maximum and minimum temperatures range from 14.2 to $17.1{ }^{\circ} \mathrm{C}$ and -1.9 to $1.4{ }^{\circ} \mathrm{C}$, respectively. The highest elevation sites were in the subalpine areas with lodgepole pine as the dominant overstory species (elevation 2700 to $2818 \mathrm{~m}$ ). These lodgepole pine sites receive an annual precipitation of $10.3 \mathrm{~cm}$ and have average maximum and minimum temperatures of 10.9 and $-1.8{ }^{\circ} \mathrm{C}$, respectively. All climate data were obtained through WRCC, 2011 [16].

Mastication treatments were conducted from 2004-2006 with a Hydro-ax@ rotary axe mower and vertical shaft as described in Battaglia et al. [15] and Rhoades et al. [16]. The masticated material at these sites consisted primarily of woody biomass that was interspersed with litter and duff during mastication creating a heterogeneous surface fuel composition in the treated sites [15]. The untreated reference sites did not experience the disturbance of mastication and contained more uniform pine needle litter $[15,16]$. Mastication treatments reduced tree basal area and shrub cover by $47 \%-89 \%$, while groundcover vegetation cover increased, particularly for grasses and forbs $[15,16]$. 


\subsection{Field Sampling}

Sampling occurred in the summer of 2012, 6-9 years following treatments along three replicate randomly located $50 \mathrm{~m}$ transects located in both masticated (treated) and nearby untreated reference locations $(N=3$ transects per treatment per site). We observed vegetation cover estimates by plant functional group (tree, graminoid, forb, shrub) for three 1-m2 quadrats along each of the pre-established transects (three quadrats per transect $\times$ six transects per site $\times$ three sites per forest type $\times$ three forest types $=162$ quadrats).

Quadrats were sampled in areas that were equal to or somewhat greater than the average mastication depth for each forest type [15] to test for the potential barrier a mastication layer may cause. We collected five forest floor depth measurements (litter, duff and $\leq 10 \mathrm{~h}$ fuels $2.54 \mathrm{~cm}$ ), also called mulch depths in the treated sites, in the four corners and the center of these same vegetation $1-\mathrm{m}^{2}$ quadrats and did not observe any significant difference between treated and untreated average forest floor depths (Kruskal Wallis $p>0.05$ ). Forest types differed significantly in their average forest floor depths (Kruskal Wallis, chi-squared $=31.6, p=0.001$ and $x_{2}=23.6, p<0.00001$ ) with ponderosa pine and lodgepole pine containing the highest median average depth $(4.0 \mathrm{~cm} \pm 0.55$ and $3.5 \mathrm{~cm} \pm$ 0.29 , respectively) and pinyon-juniper the lowest median average depths $(1.6 \mathrm{~cm} \pm 0.20)$, which agreed with previous studies at these sites $[15,16]$.

We collected seed bank samples during the peak growing season to ensure that a majority of seeds had germinated leaving only the stored propagules (i.e., the seed bank) belowground. We collected each soil seed bank sample in the center of the 1-m2 quadrats after removing all material down to the mineral soil. Using a soil bulb planter we obtained $130.5 \mathrm{~cm}_{3}$ of soil at each sampling point to a depth of $5 \mathrm{~cm}$ below the mineral soil surface. We maintained samples on ice while transporting from the field. Upon arrival at the lab, we stored the samples for 5 months in cold stratification in a $\sim 2-4{ }^{\circ} \mathrm{C}$ cold room which had been shown to break seed dormancy [34].

\subsection{Germination Methods}

Following cold stratification we sieved the soil samples through a $2 \mathrm{~mm}$ soil sieve to remove rocks and large debris and to break up soil clumps and carefully sorted through all material greater than 2 $\mathrm{mm}$ for any seeds. As we only observed one seed that did not pass through the sieve, we were confident that we had captured all seed sizes present. To standardize the soil volume used in germination trials, and to remove rocks and debris, we sifted a subset of the samples to a known stratified random volume containing $\left(100 \mathrm{~cm}_{3}\right)$ mineral soil, noting the volume if a sample contained less than this amount. This standardization allowed us to compare the density of seeds found in mineral soil from different sampling locations. We then converted the units of all samples to report the density of seeds found in one $\mathrm{L}(1000 \mathrm{~cm} 3)$ of mineral soil.

To determine viable seeds in the soil seed bank we conducted a greenhouse emergence trial at the University of Colorado, Boulder, Colorado, USA. We evenly spread the randomly assigned soil samples $(\sim 0.5 \mathrm{~cm}$ depth) over $0.5 \mathrm{~L}$ of sand in well-draining pots. We placed four additional control pots alongside the samples to evaluate if seed dispersal from nearby greenhouse plants was contaminating our samples. We observed one contaminant species from the greenhouse (Fatoua Gaudich sp. (Moraceae)) and removed this species from the data. We watered soil samples daily for 
the duration of the study to maintain even moisture levels. We initially recorded germination daily, then, as germination rates decreased we conducted observations every three days, then went over to weekly observations. We counted and recorded all morphologically distinct germinants as they emerged, terminating the trial after two weeks with no new germination (120 days). In an effort to ensure that we had depleted the seed bank after germination, we manually sorted a subset of the soil samples $(N=36)$ under $10 \times$ times magnification and did not observe any remaining seeds in the samples.

\subsection{Molecular Identification}

We implemented a DNA sequencing approach to identify or confirm identification of all unknown and known specimens. We removed $1 \mathrm{~cm}_{2}$ of leaf tissue from the specimen and pulverized it using a Spex Geno/Grinder in the molecular laboratory of E. Tripp (University of Colorado, Boulder). From these samples, we extracted DNA following a modified cetyltrimethyl ammonium bromide (CTAB) protocol [35]. For each sample, we sequenced one of three molecular markers that are among the fastest evolving Sanger loci in plants and that have reference databases represented in GenBank, for the purposes of later identification: nuclear ribosomal ITS $+5.8 S$, the chloroplast ps $b A$-trnH spacer region and the chloroplast trnL-trnF spacer. DNA was amplified via PCR using Qiagen kits, with an annealing temperature between $54-60{ }^{\circ} \mathrm{C}$. Resultant products were purified enzymatically and sequenced unidirectionally by QuintaraBio Company (Albany, CA, USA). To identify sequences to taxonomic group, 200-250 bases of the resulting sequences were run through the National Center for Biotechnology Information's n-BLAST algorithm (http://www.ncbi.nlm.nih.gov/). We considered the top 10 BLAST hits as well as hits that had a $\geq 90 \%$ sequence similarity. In general, hits with $\geq 95 \%$ sequence similarity BLASTED the sequence to genus whereas hits with $90 \%-94 \%$ sequenced similarity were resolvable only to plant family. Following molecular identification, we re- examined specimens morphologically to confirm the sensibility of molecular IDs. Our sequencing methods confirmed the identification of a majority of unknown germinants to either family or genus. In several cases, based on the known aboveground flora, we were able to further assign unknown germinants to species. We used the USDA Plants Database (www.plants.usda.gov) to confirm the most current nomenclature, native status and growth habits of specimens.

\subsection{Statistical Analyses}

To better understand variations among our explanatory variables (forest type, mastication treatment and site location) we obtained the mean number of seeds/L at the transect level for all analyses (total seed counts and individual functional group) testing for differences in forest type and treatment and looking at whether an interaction between type and treatment was present. We tested for differences between plant functional group seed densities (grass, forb, shrub, tree) using a non-parametric Kruskal-Wallis test using R software (RDC, 2014, Vienna, Austria). After finding a difference between functional group densities we analyzed total seed densities and each functional group (grass, forb, shrub) separately using the mixed model GLMMIX procedure (SAS Institute Inc., Cary, NC, USA) testing for differences in type, treatment and an interaction effect between type and treatment. For these models we used a lognormal response distribution and an identity link function. In these 
analyses the fixed effects were forest type and treatment and the random block effect was site location. Before analyses were conducted we rescaled the data according to Stahel et al. [36] to accommodate 0 values. No treatment effects were observed in any of the analyses conducted. Post-hoc analyses were conducted on total seed densities (seeds/L) by forest type using a Tukey's HSD test on square root transformed data and the difference between untreated and treated total seed densities was determined through a non-parametric two-group Mann Whitney U test (RDC, 2014, Vienna, Austria). We then divided both aboveground vegetation cover and seed bank density functional groups into proportional estimates. Through a series of chi squared tests we compared proportional differences by treatment within a forest type. Significance threshold was set at an alpha of 0.05 and a standard error of \pm 1 .

\section{Results}

\subsection{Seed Banks}

We identified 12 plant families in our seed bank samples (Table 1). Brassicaceae was the most represented family with two annual forb species, Draba cuneifolia Nutt. Ex Torr. \& A. Gray and Descurannia pinnata (Walter) Britton, representing $67 \%$ and $20 \%$ of the seeds observed in this family, respectively. Most of the taxonomic clarity was to family or genus (Table 1) yet a prominent identified annual/perennial forb species observed across multiple locations in all three forest types was Androsace septentrionalis L. (Primulaceae). We also found Campanula rotundifolia L. (Campanulaceae) and Heuchera parvifolia Bartlett (Saxifragaceae), both perennial species, mostly occurred in ponderosa pine forests but were also located in lodgepole pine forests. Our identified non-native forb species were Verbascum Thapsus L. (Scrophulariaceae), Linnaria vulgaris Mill. (Plantaginaceae) and Carduus nutans L. (Asteraceae), all of which are classified as noxious weeds by the state of Colorado, USA. We only observed these non-natives in the treated ponderosa pine sites and aside from $V$. thapsus they occurred in relatively low numbers (Table 1). We identified one invasive grass species (Bromus tectorum L., Poaceae) in a treated ponderosa pine site. A low occurrence of graminoids was a general trend throughout the seed bank. Carex L. sp. (Cyperaceae) was the most common graminoid found in all forest types regardless of treatment and Agrostis L. sp. as the most common identified grass (Poaceae) species (Table 1). We did not find any shrub seeds in the pinyon-juniper forest types and sparse shrub seeds densities in the ponderosa pine forests (average of $0.8 \pm 0.6 \mathrm{seeds} / \mathrm{L}$ for both treatments). The shrub genera and species we observed in low numbers were Rubus L. sp. (Rosaceae) and Ribes L. sp. (Grossulariaceae) and the dominant shrub species found in lodgepole pine forestes regardless of treatement was Jamesia Americana Torr. \& A. Gray (Hydrangeaceae) $(9.4 \pm 6.21$ seeds/L for untreated and $7.5 \pm 5.5$ seeds/L for treated). 
Table 1. Raw counts of seeds found in mineral soil grouped by functional group, family and genus (identified to species if positive identification was available). Each family has the total number of seeds observed including individuals that were identified further.

\begin{tabular}{|c|c|c|c|}
\hline Functional group & Family & Genus & Total Seeds \\
\hline \multirow[t]{23}{*}{ Forb } & Alsinaceae & & 5 \\
\hline & Asteraceae & & 21 \\
\hline & & Carduus nutans L.* & 1 \\
\hline & & Cirsium Mill. & 4 \\
\hline & & Erigeron L. & 14 \\
\hline & & Gnaphalium L. Pseudognaphalium Kirp & 1 \\
\hline & & Symphyotrichum Ness. & 1 \\
\hline & Boraginaceae & Mertensia Roth. & 1 \\
\hline & Brassicaceae & & 75 \\
\hline & & Alyssum L. & 1 \\
\hline & & Arabis L. & 9 \\
\hline & & Descurainia pinnata (Walter) Britton & 15 \\
\hline & & Draba cuneifolia Nutt.Ex. Torr. \& A. Gray & 50 \\
\hline & Campanulaceae & Campanula rotundifolia $\mathrm{L}$. & 17 \\
\hline & Caryophyllaceae & Silene L. & 2 \\
\hline & Fumariaceae & Corydalis DC. & 1 \\
\hline & Plantaginaceae & & 28 \\
\hline & & Linaria vulgaris Mill.* & 3 \\
\hline & & Penstemon Schmidel & 4 \\
\hline & Primulaceae & Androsace septentrionalis $L$. & 43 \\
\hline & Saxafragaceae & Heuchera parvifolia Nut. Ex Torr. \& A. Gray & 18 \\
\hline & Scrophulariaceae & Verbascum thapsus L.* & 29 \\
\hline & Unknown Forb & & 22 \\
\hline \multirow[t]{2}{*}{$\begin{array}{c}\text { Forb and/or } \\
\text { Shrub }\end{array}$} & Rosaceae: & & 18 \\
\hline & & Potentilla $\mathrm{L}$. & 15 \\
\hline \multirow[t]{8}{*}{ Graminoid } & Cyperaceae & Carex L. & 16 \\
\hline & Juncaceae & Juncus L. & 1 \\
\hline & Poaceae & & 24 \\
\hline & & Agrostis L. & 15 \\
\hline & & Bromus tectorum L.* & 1 \\
\hline & & Elymus L. & 1 \\
\hline & & Poa L. & 7 \\
\hline & Unknown Grass & & 14 \\
\hline \multirow[t]{4}{*}{ Shrub } & Grossulariaceae & Ribes L. & 1 \\
\hline & Hydrangeaceae & Jamesia americana Tor. \& A. Gray & 41 \\
\hline & Rhamnaceae & & 5 \\
\hline & & Rubus L. & 3 \\
\hline
\end{tabular}

*Denotes identified non-native species. 
After assigning individuals into their functional groups (graminoid, forb, shrub and tree) we found forbs made up the majority of the seed bank across samples (mean $19.1 \pm 4.0$ seeds/L) while graminoids and shrubs contained lower densities (mean $2.7 \pm 0.6$ seeds/L and $3.0 \pm 1.8$ seeds/L respectively). The graminoids were the only functional group that displayed a higher density of seeds in treated sites $(4.0 \pm 1.0$ seeds/L) than untreated $(1.4 \pm 0.5$ seeds/L; GLMM, $p=0.01)$; all other functional groups did not differ across treated and untreated. Forbs were the only functional group that differed by forest type (GLMM, $p=0.0008$ ) in which fewer forb seeds were found in the lodgepole pine $(6.1 \pm 1.6$ seeds/L) and pinyon-juniper $(20 \pm 5.7$ seeds/L) forests than in the ponderosa pine $(31.4 \pm 10 \mathrm{seeds} / \mathrm{L})$.

When considering total seed density responses to mastication, we observed a significant treatment effect (GLMM, $p=0.04$ ) where treated sites contained twice the density than untreated sites (33.8 \pm 7.8 versus $16.3 \pm 3.7$ seeds/L, respectively). Seed density also significantly differed across forest types (GLMM, $p=0.02$ ), with the highest density of seeds found in ponderosa pine forests $(36.4 \pm$ 10.5 seeds/L), while pinyon-juniper and lodgepole pine forests contained $23.3 \pm 6.0$ and $15.6 \pm$ 5.4 seeds/L, respectively (Figure 1).

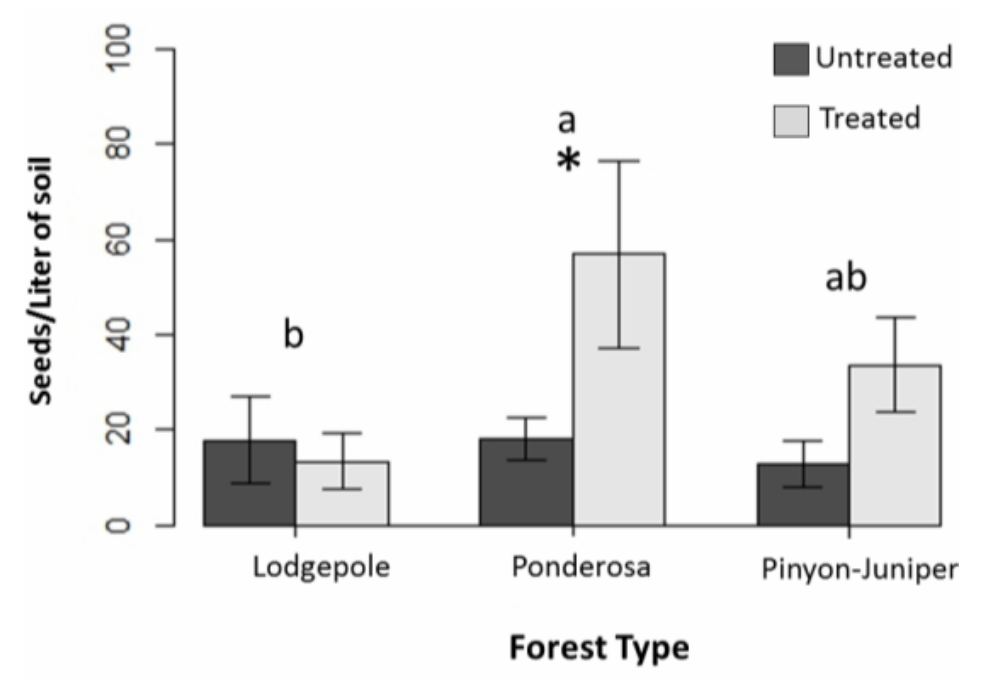

Figure 1. Seed densities per L of sifted mineral soil by forest type and treatment. Letters indicate significant differences between forest types as determined by sqrt transformed data using Tukey's HSD comparison and the asterisk indicates significance between treated and untreated within a forest type through an independent 2-group Mann-Whitney $U$ Test.

\subsection{Aboveground Vegetation}

Aboveground vegetation cover by functional groups significantly differed between treated and untreated sites for both lodgepole pine $\left(x_{2}=16.9, p=0.0007\right)$ and ponderosa pine forests $\left(x_{2}=23.73, p<0.0001\right)$, but not for pinyon-juniper sites (Figure $2 ; p>0.05$ ). Proportional abundances of functional groups were also notably different among aboveground and belowground communities, as seed banks were heavily dominated by forbs (Figure 2). 
a) Aboveground vegetation cover

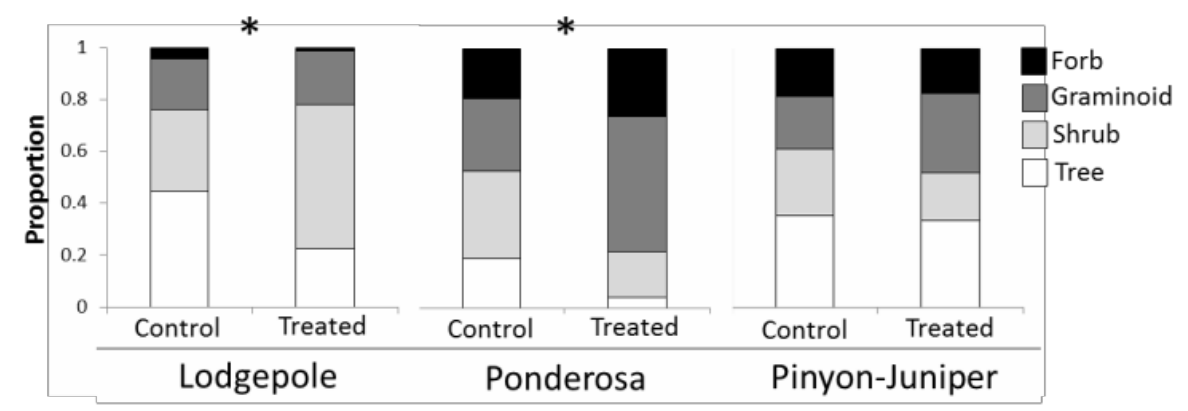

b) Seed Bank densities

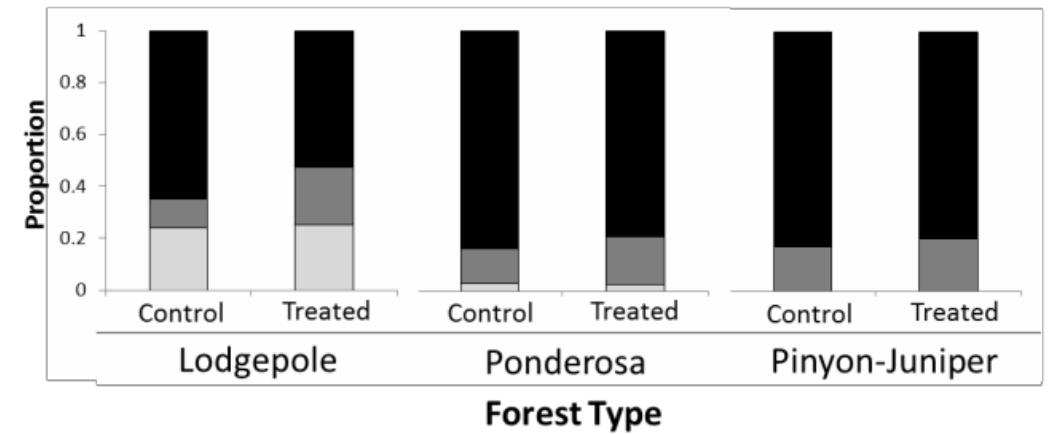

Figure 2. Proportions of plant functional groups of the (a) aboveground vegetation cover and (b) seed bank densities. Asterisks indicate significant differences $(p<0.05)$ between treatments within a forest type through pairwise chi squared tests.

\section{Discussion}

Forest thinning treatments can elicit a variety of vegetation responses depending on the method used [18-24]. As mastication deposits the plant biomass on the forest floor instead of removing it from the system, a physical barrier may be present and potentially altering seed bank compositions. Through morphological and genetic identifications, we examined soil seed bank responses to fuel reduction completed via mastication treatments across three forest types. We observed a higher density of seeds in sites treated with mastication, a result largely driven by seed densities in the ponderosa pine forest type and by the higher occurrence of graminoids in the masticated sites compared to the untreated reference sites. Seed bank densities did not differ by treatment in lodge pole pine and pinyon-juniper forest types. While not differing across treatments the forb functional group did vary by forest type with a higher density of forb seeds observed in the ponderosa pine forest type than in the lodge pole pine and intermediate densities in the pinyon-juniper type. Overall, in comparison, the aboveground plant community cover had a more even representation of functional groups, while the seed bank was strongly skewed towards forbs over any other functional group.

\subsection{Seed Banks}

Seed banks often release after disturbance to quickly colonize an area [37], and mastication can be considered one such disturbance. Our results showing forbs as the dominant seed bankers agrees with other recent seed bank studies [37,38] yet the forbs appear to be maintained in the seed bank and do 
not reach the aboveground as found in other disturbed sites [37]. Forbs seemd to be driving the difference in overall seed densities among forest types (Figure 2). This segregation by forest type can be explained by the association with niche parameters unique to the abiotic and biotic conditions of each forest type. In a similar vein, while not very high in numbers, the only identified non-native species we found were only in the treated ponderosa pine sites. Non-native species are often opportunistic colonizers of disturbed areas and thinning projects in ponderosa pine forests have been shown to invite invasives aboveground [e.g., 40], and our study suggests that this invasion can also be transferred belowground to the seed bank. This potential transference of invasives from aboveground to seed banks after mastication leads us to believe that the presence of a mastication layer may not be acting as an impenetrable barrier hindering the flow of seeds as hypothesized.

The only functional group that showed a higher occurrence of seeds across the treated and untreated sites was the graminoids. While highly species dependent, grass seeds are generally thought to be less persistent in the seed bank compared to forbs and shrubs [29,39]. Grasses, often colonize forest openings, as fuel thinning treatments are designed to thin the canopy and consequently, the understory receives increased light. This increase of grasses, whether invasive or native, in fuel treatments has been documented in a variety of thinning treatments [16,40,41], which suggests that many of the graminoids found in the seed bank were likely deposited after the mastication treatment. Even with the highly variable densities observed across the forest types this study displayed comparable seed densities to seed bank studies conducted in similar ecosystems [42-45].

\subsection{Aboveground Vegetation}

With an observed difference in proportions of aboveground functional group cover in treated versus untreated forest types - both lodgepole pine and ponderosa pine - this difference was not as pronounced in the seed bank (Figure 2). Previous studies in these systems have found that higher vegetation cover, especially in grasses and forbs, occurred in the masticated sites, yet this relationship varied by mulch depths [16]. While our study did not directly test the impacts mastication has on aboveground vegetation, we did observe a high disparity between the proportions of functional groups aboveground and in the seed bank. This discrepancy agrees with seed bank literature [46], as seed banks are often divergent from their aboveground counterparts, as they are limited by an environmental filter [47] and are stored for more appropriate environmental conditions specific to their needs [28]. Within the context of mastication the thick mulch layer could be acting as the primary environmental filter through both indirect and direct effects. The indirect effects of a mulch layer acting as an environmental filter may be the due to the reduction of light reaching the soil surface and more uniform soil temperatures not triggering germination in the thicker mulch depths [16,48]. A direct filter may be the physical mulch layer allowing for the aboveground deposition of seeds, in the form of seed rain, to enter the seed bank, but limiting their upward mobility. This downward seed transfer could be permitted because of the highly heterogeneous surface fuel structure of the masticated material $[10,11,15-18,49]$ compared to the more uniform litter of the untreated sites. With low aboveground cover observed in the higher mulch depths $[16,18]$ the influx of seeds through the mulch layer may be dispersed in from surrounding areas containing lower mulch depths that have increased vegetation cover [18]. While our data have suggested there is not a strong physical barrier limiting seed transfer in these median mulch depths as hypothesized, this study has not tested if 
germinants from the seed bank are able to push upwards through the thicker masticated layers, and additional work is needed to address this.

\section{Conclusions}

Mastication is a forest thinning treatment that incorporates shredded or chipped small diameter trees and shrubs onto the forest floor [11]. While highly variable in their ecological responses, mastication treatments often create an open canopy allowing for the inclusion of light, enhance soil moistures and increase plant available $\mathrm{N}$ and vegetation cover [16-24,49], which in turn increase the potential for seed rain and overall storage in the seed bank. Through understanding soil seed bank compositions we can begin to predict the potential future of the aboveground vegetation community and effects of a forest thinning treatment on the vegetation community as a whole. We have hypothesized that in addition to ecological effects such as changes in soil moisture and nutrients, a mastication layer presents a physical barrier for seed transfer into mineral soils. Our results, however, did not provide evidence of reductions in seed bank densities in three coniferous forest types of Colorado (USA) and actually showed increases in seed densities in masticated ponderosa pine and pinyon-juniper forests. Additionally, while not found in high numbers, the only identified non-native species found in the seed bank were found in the treated ponderosa pine sites. As we did not observe the same instance of non-native seeds in the nearby untreated sites this suggests that the mastication layer is not providing a physical barrier and is likely allowing the transfer of seeds from the aboveground vegetation to reach the seed bank. Further support for this transfer of seeds was the increase of graminoid seed density in the treated sites, a trend that was also observed aboveground in the ponderosa pine vegetation. While the total density of forbs did not differ across treatments it did differ across forest types and comprised the highest proportion of seeds compared to other functional groups. This dominance of forbs in the seed bank was not found in the aboveground vegetation cover. Overall, with higher seed bank densities found in the treated sites our study suggests that presence of a mastication layer does not deplete the soil seed bank and a seed transfer is likely in the three Colorado conifer forests tested.

\section{Acknowledgments}

We thank the University of Colorado Greenhouse (National Science Foundation grant \# BIR-9317890) for the use of their facilities during the germination process and Jeff Spitz (funded by the University of Colorado Biological Science Initiative BURST grant) for his assistance with the greenhouse germination trials. We also thank Paula Fornwalt for her help with analyses and comments, Michael Battaglia and Charles Rhoades for the use of their field sites and for comments on earlier drafts, Monique Rocca and Michael Ryan for the use of their field sites and Scott Ferrrenberg for his comments on drafts of this manuscript.

\section{Author Contributions}

The first author Akasha M. Faist conducted the fieldwork and mentored undergraduate J. Spitz for the greenhouse germination trials, analyzed the data and conducted a majority of the writing and editing of the document. Second author Heather Stone conducted the majority of the lab work associated with the molecular identification process and third author Erin A. Tripp. identified 
sequences through the National Center for Biotechnology Information's n-BLAST algorithm and was involved throughout in writing the manuscript.

\section{Conflicts of Interest}

The authors declare no conflict of interest.

\section{References}

1. Grissino-Mayer, H.D.; Romme, W.H.; Floyd, L.M.; Hanna, D.D. Climatic and human influences on fire regimes of the southern San Juan Mountains, Colorado, USA. Ecology 2004, $85,1708-1724$.

2. Westerling, A.L.; Hidalgo, H.G.; Cayan, D.R.; Swetnam, T.W. Warming and earlier spring increase western US forest wildfire activity. Science 2006, 313, 940-943.

3. Stephens, S.L.; Moghaddas, J.J.; Edminster, C.; Fiedler, C.E.; Haase, S.; Harrington, M.; Youngblood, A. Fire treatment effects on vegetation structure, fuels, and potential fire severity in western US forests. Ecol. Appl. 2009, 19, 305-320.

4. Seidl, R.; Schelhaas, M.J.; Lexer, M.J. Unraveling the drivers of intensifying forest disturbance regimes in Europe. Glob. Chang. Biol. 2002, 17, 2842-2852.

5. Stephens, S.L.; McIver, J.D.; Boerner, R.E.; Fettig, C.J.; Fontaine, J.B.; Hartsough, B.R.; Schwilk, D.W. The effects of forest fuel-reduction treatments in the United States. BioScience 2012, 62, 549-560.

6. Rocca, M.E.; Brown, P.M.; MacDonald, L.H.; Carrico, C.M. Climate change impacts on fire regimes and key ecosystem services in Rocky Mountain forests. For. Ecol. Manag. 2014, 327, 290-305.

7. Stephens, S.L.; Ruth, L.W. Federal forest-fire policy in the United States. Ecol. Appl. 2005, $15,532-542$.

8. Knapp, E.E.; Varner, J.M.; Busse, M.D.; Skinner, C.N.; Shestak, C.J. Behaviour and effects of prescribed fire in masticated fuelbeds. Int. J. Wildland Fire 2012, 20, 932-945.

9. Ryan, K.C.; Knapp, E.E.; Varner, J.M. Prescribed fire in North American forests and woodlands: History, current practice, and challenges. Front. Ecol. Environ. 2013, 11, e15-e24.

10. Kreye, J.K.; Brewer, N.W.; Morgan, P.; Varner, J.M.; Smith A.M.S.; Hoffman, C.M.; Ottmar, R.D. Fire behavior in masticated fuels: A review. For. Ecol. Manag. 2014, 314,193-207.

11. Kreye, J.K.; Kobziar, L.N.; Zipperer, W.C. Effects of fuel load and moisture content on fire behavior and heating in masticated litter-dominated fuels. Int. J. Wildland Fire 2013, 22,440-445.

12. Vitorelo, B.; Han, H.S.; Varner, J.M. Masticators for fuel reduction treatment: Equipment options, effectiveness, costs, and environmental impacts. In Proceedings of Council On Forest Engineering (COFE) meeting, Lake Tahoe, CA, USA, June 15-18, 2009; p. 11.

13. Reiner, A.L.; Vaillant, N.M.; Fites-Kaufman, J.; Dailey, S.N. Mastication and prescribed fire impacts on fuels in a 25-year old ponderosa pine plantation, southern Sierra Nevada. Forest Ecol. Manag. 2009, 258, 2365-2372.

14. Kreye, J.K.; Varner, J.M.; Knapp, E.E. Effects of particle fracturing and moisture content on fire behaviour in masticated fuelbeds burned in a laboratory. Int. J. Wildland Fire 2011, 20, 308-317. 
15. Battaglia, M.A.; Rocca, M.E.; Rhoades, C.C.; Ryan, M.G. Surface fuel loadings within mulching treatments in Colorado coniferous forests. For. Ecol. Manag. 2010, 260, 1557-1566.

16. Rhoades, C.C.; Battaglia, M.A.; Rocca, M.E.; Ryan, M.G. Short-and medium-term effects of fuel reduction mulch treatments on soil nitrogen availability in Colorado conifer forests. For. Ecol. Manag. 2012, 276, 231-238.

17. Kane, J.M.; Varner, J.M.; Knapp, E.E. Novel fuel bed characteristics associated with mechanical mastication treatments in northern California and south-western Oregon, USA. Int. J. Wildland Fire 2009, 18, 686-697.

18. Wolk, B.; Rocca. M.E. Thinning and chipping small-diameter ponderosa pine changes understory plant communities on the Colorado Front Range. For. Ecol. Manag. 2009, 1, 85-95.

19. Brockwa, D.G.; Outcalt, K.W.; Estes, B.L.; Rummer, R.B. Vegetation response to midstorey mulching and prescribed burning for wildfire hazard reduction and longleaf pine (Pinus palustrus Mill.) ecosystem restoration. Forestry 2009, 82, 299-314.

20. Kane, J.M.; Varner, J.M.; Knapp, E.E.; Powers, R.F. Understory vegetation response to mechanical mastication and other fuels treatments in a ponderosa pine forest. Appl. Veg. Sci. 2010, 13, 207-220.

21. Ross, M.R.; Castle, S.C.; Barger, N.N. Effects of fuels reductions on plant communities and soils in a Piñon-juniper woodland. J. Arid. Environ. 2012, 79, 84-92.

22. Collins, B.M.; Moghaddas, J.J.; Stephens, S.L. Initial changes in forest structure and understory plant communities following fuel reduction activities in a Sierra Nevada mixed conifer forest. For. Ecol. Manag. 2007, 239, 102-111.

23. Young, K.R.; Roundy, B.A.; Eggett, D.L. Plant establishment in masticated Utah juniper woodlands. Rangeland Ecol. Manag. 2013, 66, 597-607.

24. Redmond, M.D.; Zelikova, T.J.; Barger, N.N. Limits to understory plant restoration following fuel-reduction treatments in a piñon-juniper woodland. Environ. Manag. 2014, 54, 1139-1152.

25. Warner, R.R.; Chesson, P. Coexistence mediated by recruitment fluctuations a field guide to the storage effect. Am. Nat. 1985, 125,769-787.

26. Ooi, M.K.; Auld, T.D.; Denham, A.J. Projected soil temperature increase and seed dormancy response along an altitudinal gradient: Implications for seed bank persistence under climate change. Plant Soil 2012, 353, 289-303.

27. Brock, M.A.; Rogers, K.H. The regeneration potential of the seed bank of an ephemeral floodplain in South Africa. Aquat. Bot. 1998, 61, 123-135.

28. Facelli, J.M.; Chesson, P.; Barnes, N. Differences in seed biology of annual plants in arid lands: A key ingredient of the storage effect. Ecology 2005, 86, 2998-3006.

29. Faist, A.M.; Ferrenberg, S.; Collinge, S.K. Banking on the past: Seed banks as a reservoir for rareand native species in restored vernal pools. AoB PLANTS 2013, 5, 1-11.

30. Thompson, K.; Grime, J.P. Seasonal variation in the seed banks of herbaceous species in ten contrasting habitats. J. Ecol. 1979, 3, 893-921.

31. Whelan, R.J. The Ecology of Fire; Cambridge University Press: Cambridge, UK, 1995. 
32. Belnap, J. Surface disturbances: Their role in accelerating desertification. Environ. Monit. Assess 1995, 37, 39-57.

33. Pakeman, R.J.; Small, J.L. The role of the seed bank, seed rain and the timing of disturbance in gap regeneration. J. Veg. Sci. 2005, 16, 121-130.

34. Baskin, C.C.; Baskin, J.M. Seeds: Ecology, Biogeography, and Evolution of Dormancy and Germination; Academic Press: San Diego, CA, USA, 2001.

35. Doyle, J.J.; Doyle, J.L. A rapid isolation procedure for small quantities of fresh leaf tissue. Phytochem. Bull. 1987, 19, 11-15.

36. Stahel, W.A. Statistische Datenanalyse: Eine Einführung Für Naturwissenschaftler (Statistical Data Analysis: An Introduction for Scientists); Vieweg Publishing House: Brunswick, Germany, 2002. (In Germany)

37. Bakker, C.; Graaf, H.F.; Ernst, W.H.; Bodegom, P.M. Does the seed bank contribute to the restoration of species-rich vegetation in wet dune slacks? Appl. Veg. Sci. 2005, 8, 39-48

38. Korb, J.E.; Springer, J.D.; Powers, S.R.; Moore, M.M. Soil seed banks in Pinus ponderosa forests in Arizona: Clues to site history and restoration potential. Appl. Veg. Sci. 2005, 8, 103-112.

39. Thompson, K.B.; Band, S.R.; Hodgson, J.G. Seed size and shape predict persistence in soil. Funct. Ecol. 1993, 7, 236-241

40. Griffis, K.L.; Crawford, J.A.; Wagner, M.R.; Moir, W.H. Understory response to management treatments in northern Arizona ponderosa pine forests. For. Ecol. Manag. 2001, 146, 239-245.

41. Huffman, D.W.; Stoddard, M.T.; Springer, J.D.; Crouse, J.E.; Chancellor, W.W. Understory plant community responses to hazardous fuels reduction treatments in pinyon-juniper woodlands of Arizona, USA. For. Ecol. Manag. 2013, 289, 478-488.

42. Wienk, C.L.; Sieg, C.H.; McPherson, G.R. Evaluating the role of cutting treatments, fire and soil seed banks in an experimental framework in ponderosa pine forests of the Black Hills, South Dakota. For. Ecol. Manag. 2004, 192, 375-393.

43. Halpern, C.B.; Evans, S.A.; Nielson, S. Soil seed banks in young, closed-canopy forests of the Olympic Peninsula, Washington: Potential contributions to understory reinitiation. Can. J. Bot. 1999, 77, 922-935.

44. Zobel, M.; Kalamees, R.; Püssa, K.; Roosaluste, E.; Moora, M. Soil seed bank and vegetation in mixed coniferous forest stands with different disturbance regimes. For. Ecol. Manag. 2007, 250, 71-76.

45. Abella, S.R.; Springer, J.D. Soil seed banks in a mature coniferous forest landscape: Dominance of native perennials and low spatial variability. Seed. Sci. Res. 2012, 22, 207-217.

46. Hopfensperger, K.N. A review of similarity between seed bank and standing vegetation across ecosystems. Oikos 2007, 116, 1438-1448.

47. Faist, A.M.; Collinge, S.K. Seed bank composition varies along invasion and inundation gradients in vernal pools. Plant Ecol. 2015, 216, 553-564.

48. Vleeshouwers, L.M.; Bouwmeester, H.J.; Karssen, C.M. Redefining seed dormancy: An attempt to integrate physiology and ecology. J. Ecol. 1995, 6, 1031-1037. 
49. Miller, E.M.; Seastedt, T.R. Impacts of woodchip amendments and soil nutrient availability on understory vegetation establishment following thinning of a ponderosa pine forest. For. Ecol. Manag. 2009, 258, 263-272.

(C) 2015 by the authors; licensee MDPI, Basel, Switzerland. This article is an open access article distributed under the terms and conditions of the Creative Commons Attribution license (http://creativecommons.org/licenses/by/4.0/). 